\title{
OPEN GOVERNMENT PARTNERSHIP IN INDONESIA ${ }^{1}$
}

\author{
Achmad Zulfikar ${ }^{2}$
}

\begin{abstract}
This paper aims to disseminate information on Open Government Partnership (OGP) in Indonesia, in particular to examine the extent to which civil society organizations (CSOs) are involved. This paper uses qualitative methods with data collection through literature review sourced from online document. The data analysis process through data reduction, data presentation, and conclusion is done simultaneously with data collection process. This paper reveals five issues: the reason of Indonesia joining the Open Government Partnership, the involvement and welfare of Indonesia CSOs in the Implementation of OGP Program, the cooperation between Indonesia CSOs and Government in the OGP Matters, and greatest achievements of the OGP in Indonesia. The conclusion of OGP's progress in Indonesia is that the Indonesian government together with CSOs have synergized to jointly realize Indonesia's commitment to realize good governance. Nevertheless, the scope of synergized areas is still limited, therefore broader cooperation and more coordinated networks are needed to reach all areas of public services to bring about openness, accountability and public participation.
\end{abstract}

Keywords: Open Government, Openness, Accountability, Public Participation

\section{INTRODUCTION}

Open Government Partnership has been established by eight countries in 2011 including: Brazil, Indonesia, Mexico, Norway, the Philippines, South Africa, the United Kingdom and the United States. Indonesia is one of the founding countries. Nevertheless, the scientific study of Open Government Partnership in Indonesia is still lacking, making it difficult for researchers and observers to understand its progress in a concise, yet comprehensive way.

This paper aims to disseminate information on Open Government Partnership in Indonesia, in particular to see the extent of civil society involvement. This paper is the result of correspondence with one of the researchers and journalists from South Africa who are conducting a comparative study between South Africa, Georgia and Indonesia.

\footnotetext{
${ }^{1}$ This paper is the result of the development of correspondence with a Researcher and Journalist from South Africa, February 2018.

${ }^{2}$ Currently in Department of International Relations Universitas Muhammadiyah Yogyakarta. I am also a Researcher in Makassar Development Institute, an non-governmental organization and has been done with internship as Media and Communication Analyst in Open Government Indonesia Secretariat Batch VII Period January to May 2014. Email: apa@kabarfikar.com.
} 
Five questions that attempt to be answered: (1) why did Indonesia join the Open Government Partnership?, (2) how widely known is the OGP in Indonesia, specifically in the awareness of the OGP among civil society groups?, (3) has civil society in Indonesia been able to influence the process - if so in what way?, (4) how have civil society and government been able to cooperate on OGP matters?, and (5) what would you regard as the greatest achievements of the OGP in Indonesia?. These five questions described in the results and discussion sections.

\section{METHODS}

This paper uses qualitative methods with data collection through literature review sourced from online documents on matters related to Open Government Partnership in Indonesia. The process of data analysis is data reduction, data presentation, and conclusion is done simultaneously with data collection process.

\section{RESULTS AND DISCUSSION}

\section{The Reason of Indonesia Join the Open Government Partnership}

Indonesia is one of the eight founding countries of the Open Government Partnership (OGP) in 2011 with Brazil, Mexico, Norway, the Philippines, South Africa, the United Kingdom and the United States. Indonesia in September 2012, for one year became the supporting co-chair of OGP together with the UK as the leading co-chair. Then for the next year, September 2013 to September 2014, Indonesia became the leading co-chair to replace the UK, along with Mexico who became the supporting co-chair.

Indonesia's leadership in the Open Government Partnership promotes improvement efforts within the country where Indonesia should demonstrate its commitment to change towards a better direction. Indonesia should be able to inspire efforts towards transparency, improving service quality, and increasing citizen participation in government. This is also the reason why Indonesia participated in the Open Government Partnership.

This reason was affirmed by President Susilo Bambang Yudhoyono in one of his speeches on 16th August 2012 stating that "We must complete the management of government by the expansion of public participation starting from the participation of development until opening up public access in order to participate in the control of government management. This is the essence of open government". 


\section{Involvement and Awareness of Indonesia Civil Society Organizations in OGP}

Open Government Partnership is an intergovernmental organization that has unique characteristics. OGP has mechanisms and work patterns that involve the public as part of the comprehensive process, so that the role of civil society groups is needed in carrying out Open Government functions. This is reflected in the process of joining as an OGP member, participating countries must endorse a high-level Open Government Declaration, delivering a country action plan developed with a public consultation, and committing to independent reporting on their progress going forward. Until today, over 70 OGP participating countries and 15 sub-national governments have made over 2,500 commitments to make their government more open and accountable. In this case, Indonesia as one of the OGP members and also the founder of OGP has "Core Team" Open Government Indonesia. (See Attachment 1).

Referred to the Open Government Partnership website in an article entitled "Background to the Open Government Partnership in Indonesia: The CSO Core Team" the first step in the development of OGP in Indonesia was the government's establishment of Open Government Indonesia (OGI). The government established OGI as a platform for communication between interested parties. Initially, OGI had a core team consisting of five government agencies, namely, the President's Delivery Unit for Development Monitoring and Oversight (UKP-PPP), Ministry of Foreign Affairs, Ministry of Communication and Information, National Planning Agency, and Central Information Commission. The government subsequently appointed four civil society organizations (CSO) to join the OGI Core Team. However, as there were no mechanisms for the appointment of these CSOs, there were concerns about transparency of these selections. The appointed CSOs, therefore, asked for explanations regarding the reasons behind their respective appointments. The government responded by announcing that the credibility of each organization as a representative of their distinct and different backgrounds was behind their appointments and that this credibility would serve to start building trust between government and CSOs.

In 2013, the Indonesia government decided to add another two government agencies to the core team, the Ministry of Administrative Reform and Ministry of Home Affairs. As a result of this extension, civil society core team members requested a further extension of the team, in order to provide equal representative for government and civil society. An open recruitment process was conducted and three organizations with different backgrounds were chosen, based on criteria set during discussions between government and the CSO Core Team.

Despite the increased prominence of the CSOs within Open Government, the CSOs' internal mechanisms had yet to reach the maximum capacity. Of particular concern for the CSOs, at this time, was a lack of resources and dedicated personnel from each organization (focal point). In response to these limitations, the CSO Core Team conducted a process of self-restructuring, following the OGP London Summit in 2013. As a result, each 
organization appointed a focal point to sit in the OGI Core Team, with the core team appointing an internal coordinator and establishing a secretariat. In addition to that, the seven CSOs were also divided into specific roles, with specific functions. The division of tasks was based on their focus areas (anti-corruption, environmental matters, public service, budget transparency, and legislative openness) and the different scale of their operations (international, national, and sub-national level).

The focus areas of each sector include: (1) anti-corruption: Transparency International Indonesia with the task of collaborative efforts for essential services with integrity and websites accessible through: http:/ / www.ti.or.id/ en/ and GerAk Aceh (Aceh Anti-Corruption Movement) with the task of collaborative efforts with sub-national government for an accountable government with integrity and websites accessible through: http:// www.gerakaceh.org/ ; (2) budget transparency: SekNas FITRA (National Secretariat for Indonesian Forum for Budget Transparency) with the task of collaborative efforts in pursuing budget transparency in three pillars: executive, legislative, and communities and websites accessible through: http://seknasfitra.org/?lang=en; (3) environment: ICEL (Indonesian Center for Environmental Law) with the task of collaborative efforts in access to information, participation, environmental justice and natural resources management and website accessible through: http:/ / www.icel.or.id/ and JARI KalTeng (Central Kalimantan Civil Society Independent Network for Transparency and Accountability in Development) with the task of collaborative efforts for more responsive sub-national governance and websites accessible through: http://jarikalteng.or.id/ ; (4) public service: PATTIRO (Center for Regional and Information Studies) with the task of collaborative efforts for more transparent and accountable public service delivery and accessible websites: http:// pattiro.org/ ?lang=en and (5) legislative (sub-national): Makassar KOPEL (Makassar Legislative Monitoring Committee) with the task of collaborative efforts with local parliament to strengthen the oversight function of subnational parliament and accessible website: http:/ / kopel-online.or.id/ .

Based on the above explanation, it can be understood that OGP in Indonesia is well known widely by civil society groups even OGP as an international intergovernmental organization has a unique system by combining the role of government in implementing Open Government program and also under supervision by CSO. So that synergy between government and CSO can be achieved in OGimplementation in Indonesia.

\section{Influence of Indonesia CSOs in the Implementation of OGP Program}

CSOs in Indonesia have been involved since Indonesia's participation in OGP. This is growing until 2013, CSO core teams realize that this increasing awareness of structural limitations occurred not only within the structure of the core team, but also within the government and CSOs themselves. A lack of internal resources made them realize that public campaigning and involvement must be broadened, leading to significant public 
outreach being conducted. The engagement of a broader set of actors, including the coalition of Freedom of Information Network Indonesia, was one of the most significant approachs undertaken by the CSO Core Team. A group of CSOs also conducted an independent monitoring report to evaluate the national action plan in 2013.

During the Indonesian chairmanship, the CSO Core Team decided to take a more proactive approach to allow for better engagement and collaboration in the decision making processes for OGP initiatives. The trust which has flourished in the past two and a half years has resulted in better collaboration, whilst there is still a lot of room for improvement.

Partnership in Open Government focuses strongly on collaborative efforts, such as the efforts which have been undertaken by the seven members of the CSO Core Team. Three important forms of collaboration that has taken place between CSOs and the government have included, capacity building (i.e. provide technical assistance and training), system/infrastructure installment, and advocacy (i.e. drafting regulation with inputs from society, ensuring compliance of public agency, holding a social accountability forum, and conducting public campaign and outreach).

Based on the above explanation it can be understood that CSO in Indonesia has been able to give influence in the implementation of Open Government in Indonesia. This is evident from the development undertaken by CSO Team in providing monitoring and oversight to the government. Collaboration between government and CSO can be seen in the form of capacity building, system/ infrastructure installment and advocacy.

\section{Cooperation between Indonesia CSOs and Government in the OGP Matters}

As explained in the previous section that CSOs and governments have cooperated in implementing Open Government principles. Collaboration between CSO and government can be read in the document "Indonesia's Open Government Partnership Chairmanship 2014: Unleashing Public Participation-Nourishing the Essence of Openness" (Link attached in the reference).

The document contains a study of the achievements of the Indonesian government divided into (1) Strategic Context, (2) Indonesia's Plan on Strengthening Domestic Public Participation with derivation on (a) deepening; (b) broadening and (c) measuring success at the local level, (3) Indonesia's Plan on Reinvigorating Global Public Participation with derivation on (a) Indonesia's OGP Programs on Public Participation and (b) Measuring Success at the Global Level.

In addition the collaboration between government and CSOs, the role of other civil society that is not institutionalized, one of them is youth. In the Internship period at Open Government Indonesia, author as Media and Communication Analyst conducted independent research to mapping the knowledge of Indonesian youth on issues of openness and their level of knowledge on Open Government Indonesia. The survey was 
followed by 153 respondents consisting of $46 \%$ of men and $54 \%$ of women with an average age of respondent 22 years old. There are four core questions about the knowledge of young Indonesians on issues of openness.

First, how important the open government to you? and the results show that $82 \%$ of respondents stated very important, $17 \%$ stated important, and only $1 \%$ stated not important. Second, Is the Indonesian government has been more open? and the results show $51 \%$ say Yes, $41 \%$ say No and only $8 \%$ say Not Know. Third, How important the involvement of youth in open government? And the result is $99 \%$ say Yes, and only $1 \%$ states No. Fourth, Do you want/ have been involved in the open government movement that existing? And the result is $84 \%$ states Yes and only $16 \%$ states No. (See Attachment 2)

The results of the survey I bring to the Open Government Partnership Asia Pacific Regional Conference as Youth Delegation. This survey is aimed to address the youth aspiration to find out the relevant knowledge of government openness, involvement and response to efforts made by the government. This survey has been carried out for 1 month from February 10 to March 17, 2014. At the end of the program, 254 respondents from various parts of Indonesia collected. A special session of youth in the OGP Asia Pacific Regional Conference series entitled "Sustaining the Open Government Partnership: Youth As New Agent of Open Governance" organized by UKP-PPP on May 7, 2014 and followed by 71 youths from Asia Pacific region.

In addition, OGI also initiated the program of The Indonesian Young Ambassadors for Open Government (YAOG) which is tasked to conduct several activities throughout the year to reach out and engage with youth around Indonesia by involving communities, initiating projects, and campaigning openness narrative. YAOG initiated the Open Government Partnership Model and attended the OGP London Summit in November 2013. There are several missions that the YAOG needs to accomplish: (a) disseminate information about Open Government Partnership and their countries' open government commitments as well as action plans, both to national and international level; (b) engage with youth and student organizations to increase youth awareness on open government; and (c) improve youth's literacy on transparency, openness, accountability, and participation.

\section{Greatest Achievements of the OGP in Indonesia}

Government collaboration and CSOs has been started since OGP was established in 2011. Following the launch of OGP, the government and CSOs jointly discussed the Action Plan (Rencana Aksi/ Renaksi) which is the main instrument for ensuring the sustainability of ideas, ideas and collaboration to carrying out the principles of open government in Indonesia. Currently Renaksi has entered its seventh year of implementation which has taken place in the period of 2012, 2013, 2014-2015, 2015-2017 and 2018-2019.

The greatest achievements of the OGP in Indonesia occur in 2014. Among them are: (1) In January-February held inputs of OGP Action Plan 2014-2015 by civil society, (2) In 
March issued of Presidential Decree No. 13 of Year 2014 on the Stipulation of Indonesia's Membership in OGP, (3) In April issued Presidential Decree No. 15 of Year 2014 on the National Committee for OGP Asia-Pacific Regional Meeting 2014 (4) In May held OGP Asia Pacific Civil Society Day and Open Government Partnership Asia Pacific Regional Conference in Nusa Dua Bali, (5) In August conducted follow-up implementation of OGP Asia Pacific Regional Conference in the three regions of the Western Region, Central Region and Eastern Region, and the publication of the OGP Indonesia Action Plan 2014-2015, (6) In September held the delivery of OGP Chairman from Indonesia to Mexico, (7) In October is the inauguration of the President of the Republic of Indonesia elected the results of the 2014 Presidential and Vice Presidential Election, as well as the OGP outreach in Asia Pacific in Malaysia and Cambodia and (8) In November the National Consolidated Civil Society of OGP and the Formation of 6 Civil Society Working Groups for OGP.

In addition, OGI also initiated an Open Government Competition. In this competition 62 public services are competing to improve the quality of their public services. Some of the improvements seen in this competition include more transparent radio frequency permit fees with cost simulations at the Ministry of Communications and Informatics website, the holding of subscriber meetings at the Nuclear Power Agency to capture inputs, and the more efficient the licensing process by cutting processing time in Inatrade Ministry of Trade. Other breakthrough efforts in open government in Indonesia include the establishment of a "One Service" portal, which will contain hundreds of citizen information service modules, ranging from passport construction to information on electrical installation costs. While from the institutional side, Open Government in Indonesia also encourages the formation of Information and Documentation Management Officer (PPID) in all ministries, Institutions and local government in order to bring information closer to the public.

Referred to worldbank.org, President Susilo Bambang Yudhoyono in the OGP Asia Pacific Regional Conference in Bali delivered public service innovations resulting from the implementation of Open Government in Indonesia, such as the "One Service Information portal (http:/ / satulayanan.net),"One Government"(http:/ / satupemerintah.net), "One Map" (http:/ / tanahair.indonesia.go.id), and LAPOR! (http:/ / lapor.ukp.go.id).

\section{CONCLUSIONS}

Indonesia has joined the Open Government Partnership since 2011 and even became one of the founding countries. The reason for Indonesia's joining into OGP according to President Susilo Bambang Yudhoyono is that the government should support the expansion of government governance through public participation and open access to monitor government performance which is the essence of open government. Furthermore, related to the synergy between government and Civil Society Organizations (CSOs) within the OGP framework has been set in the oversight function in government commitments affirmed in the country action plan. Currently CSOs Indonesia is still focused on anti- 
corruption, environmental matters, public service, budget transparency, and legislative openness. While the influence of CSOs in the implementation of OGP program can be seen from the process of capacity building (i.e. provide technical assistance and training), system/infrastructure installment, and advocacy (i.e. drafting regulation with inputs from society, ensuring compliance of public agency, holding a social accountability forum, and conducting public campaign and outreach).

Based on five matters: the reason of Indonesia join the Open Government Partnership, the involvement and welfare of Indonesia civil society organizations in OGP, the influence of Indonesia CSOs in the Implementation of OGP program, the cooperation between Indonesia CSOs and Government in the OGP Matters, and greatest achievements of the OGP in Indonesia. So it can be concluded that, the OGP in Indonesia has shown progress that the Indonesian government together with CSOs have synergized to jointly realize Indonesia's commitment to realize good governance. Nevertheless, the scope of synergized areas is still limited, therefore broader cooperation and more coordinated networks are needed to reach all areas of public services to bring about openness, accountability and public participation.

\section{REFERENCE}

Kebebasaninformasi.org. Kaleidoskop Open Government Partnership Indonesia 2014. Retrieved from http:/ / kebebasaninformasi.org/ wpcontent/ uploads/ 2015/ 01/ Kaleidoskop-Open-Goverment-Partnership-Indonesia2014.pdf

Open Government Indonesia. Indonesia Menjadi Co-Chari Open Government Partnership. Retrieved from http:/ / opengovindonesia.org/ news/ 62/ indonesia-menjadi-co-chair-opengovernment-partnership.

Open Government Indonesia. Rencana Aksi 2016-2017. Retrieved from http:/ / opengovindonesia.org/ renaksi/ 4/ 2016-2017

Open Government Partnership. About Open Government Partnership. Retrieved from: https:/ / www.opengovpartnership.org/ about/ about-ogp.

Open Government Partnership. Background Open Governmnet Partnership Indonesia CSO Core Team. Retrieved from https:/ / www.opengovpartnership.org/ stories/ backgroundopen-government-partnership-indonesia-cso-core-team.

Open Government Partnership. OGP Indonesia Chairmanship 2014. Retrieved from: https:/ / www.opengovpartnership.org/ sites/ default/ files/ OGP\%20Indonesia\%20Chairma nship\%202014_final.pdf.

World Bank. Indonesia Government and Civil Society in Partnership to Encourage Greater Data Transparency. Retrieved from http:/ / www.worldbank.org/ in/ news/ pressrelease/ 2014/ 09/ 05/ indonesia-government-and-civil-society-in-partnership-toencourage-greater-data-transparency 
Attachment 1

Core Team of Open Government Indonesia

\section{Core Team OGI}

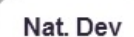

Agency Government

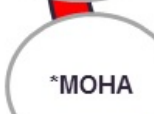
UKP4

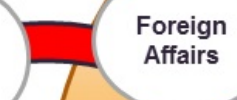
airs *MOHA
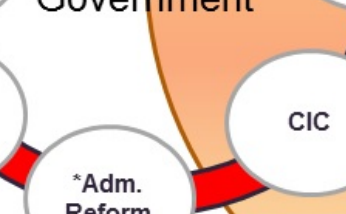

Comm. Info

Reform

CIC

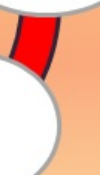

OGI Secretariat

:hosted by

UKP4

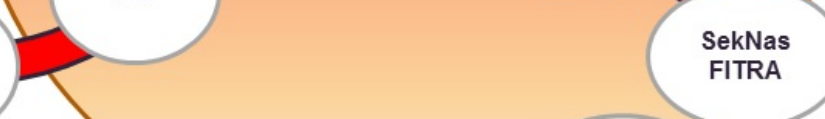

ICEL

* Joined in 2013 


\title{
Attachment 2
}

Open Government Indonesia Youth Openness Survey! (OGI YES!) 2014

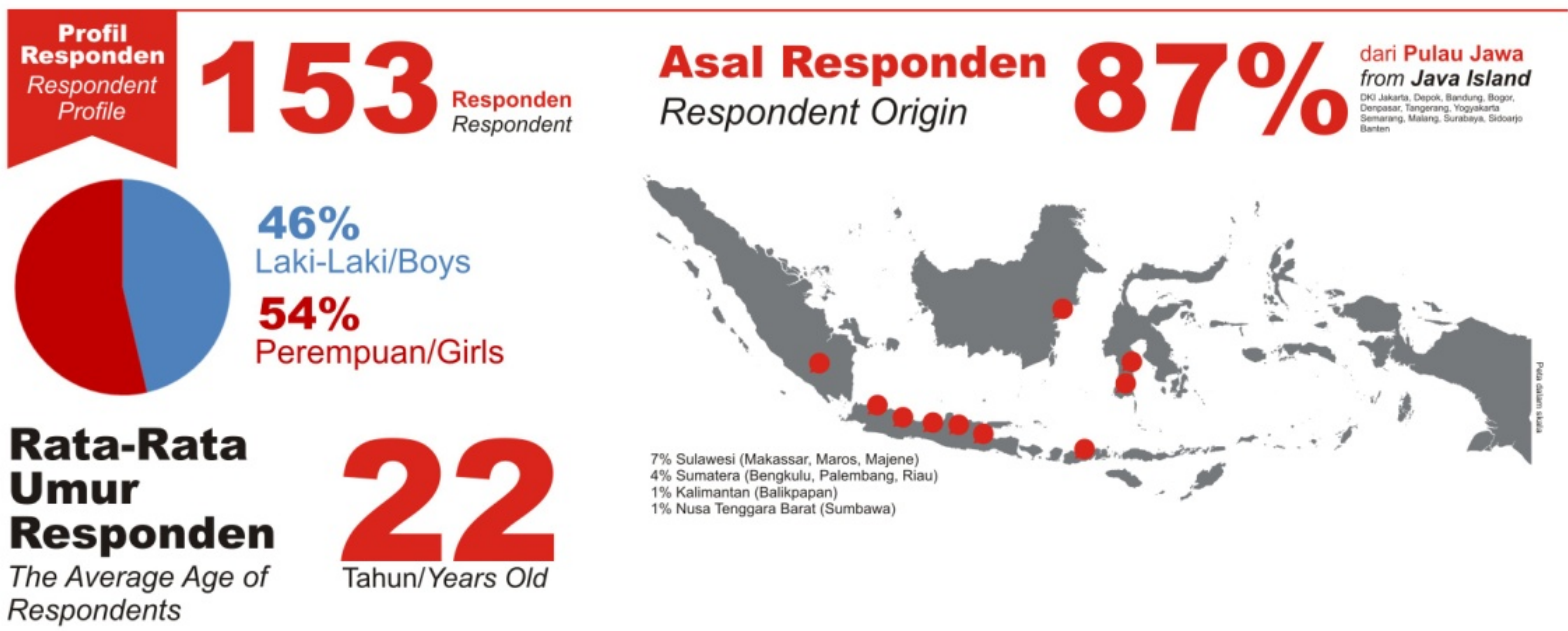

\section{Pentingkah Keterbukaan Pemerintah?}

How important the open government to you?

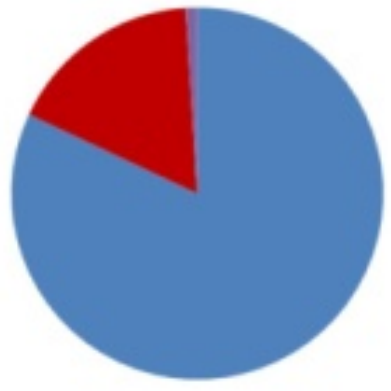

\author{
Sangat Penting / Very Important $82 \%$ \\ Penting / Important $17 \%$ \\ Kurang Penting / Less Important 0\% \\ Tidak Penting / Not Important $1 \%$
}

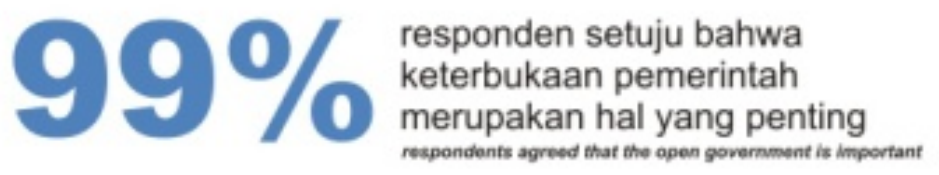

\section{Apakah pemerintah Indonesia sudah semakin terbuka?} Is the Indonesian government has been more open?

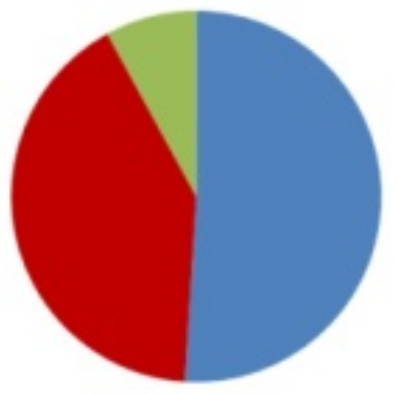

Ya/ Yes $51 \%$

Tidak / No $41 \%$

Tidak Tahu / Skip 8\%

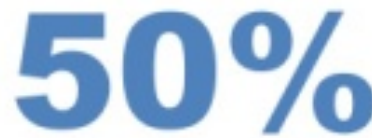

lebih responden menilai bahwa pemerintah Indonesia sudah

semakin terbuka

more respondents considered that

Indonesian government had more open 
Pentingkah keterlibatan anak muda dalam keterbukaan pemerintah? How important the involvement of youth in open government ?

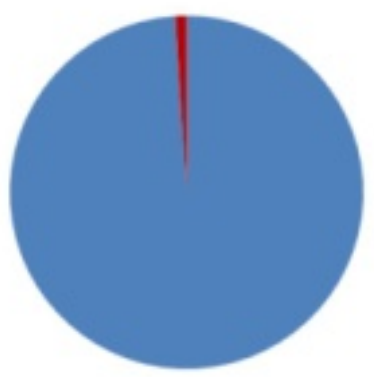

\section{Ya / Yes 99\%}

Tidak / No $1 \%$

Tidak Tahu / Skip 0\%

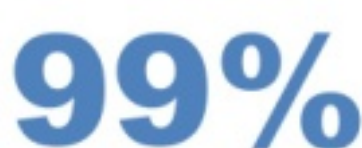

responden setuju bahwa keterlibatan anak muda dalam keterbukaan pemerintah merupakan hal yang penting respondents agreed that the involvement of youth in open government is important

\section{Apakah kamu ingin/sudah terlibat dalam gerakan keterbukaan pemerintah yang ada? \\ Do you want/have been involved in the open government movement that existing?}

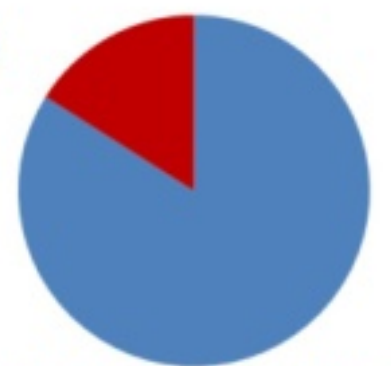

Ya / Yes 84\% | Tidak / No 16\%

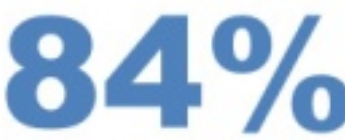

responden ingin/sudah terlibat dalam gerakan keterbukaan pemerintah yang ada

respondents wanthave been involved in the open government movement that existing

Source: Unpublished Mid-Term Infographic from Achmad Zulfikar, MedCom Internship OGI Secretariat Batch VII, 2014. 